\title{
Modelling the Water Absorption Characteristics of Different Maize (Zea Mays L.) Types during Soaking
}

\author{
Agarry $\mathrm{SE}^{1 *}$, Afolabi TJ1 and Akintunde TTY2
}

${ }^{1}$ Department of Chemical Engineering, Ladoke Akintola University of Technology, Ogbomoso, Nigeria

${ }^{2}$ Department of Food Science and Engineering, Ladoke Akintola University of Technology, Ogbomoso, Nigeria

\begin{abstract}
Water absorption characteristic of six different types of maize namely; dent corn (white and yellow), corn flour (white and yellow), popcorn and sweet corn during water soaking were studied at four different temperatures of $30,40,50$ and $60^{\circ} \mathrm{C}$. The water absorption data fitted very well into both Peleg's and Becker's models as to correspondingly determine the saturation moisture content (hydration equilibrium moisture content) and moisture diffusivity. The water absorption capacity and saturation moisture contents of each maize type increased as the water soaking temperature increased. The absorption kinetics followed the Fick's law of diffusion during the first hours of soaking. The determined diffusion coefficients values varied from 10.6 to $13.5 \times 10^{-11} \mathrm{~m}^{2} / \mathrm{s}$ for sweet corn, 6.74 to $8.88 \times 10^{-11} \mathrm{~m}^{2} / \mathrm{s}$ for white flour, 5.27 to $7.09 \times 10^{-11} \mathrm{~m}^{2} / \mathrm{s}$ for yellow flour, 4.44 to $5.79 \times 10^{-11} \mathrm{~m}^{2} / \mathrm{s}$ for popcorn, 4.25 to $5.69 \times 10^{-11} \mathrm{~m}^{2} / \mathrm{s}$ for dent white corn and 3.28 to $4.68 \times 10^{-11} \mathrm{~m}^{2} / \mathrm{s}$ for dent yellow corn, respectively. An Arrhenius-type equation was used to relate the moisture diffusivity (diffusion coefficient) of dent corn (white and yellow), corn flour (white and yellow), popcorn and sweet corn to temperature, and the energy of activation for dent corn (white and yellow), corn flour (white and yellow), popcorn and sweet corn was estimated. The values determined were 8.17, 9.59, 7.83, 8.45, 6.61 and $8.01 \mathrm{~kJ} / \mathrm{mol}$ for dent white corn, dent yellow corn, white corn flour, yellow corn flour, sweet corn and popcorn, respectively.
\end{abstract}

Keywords: Maize varieties; Water absorption; Peleg's model; Becker's model; Arrhenius-type equation

\section{Introduction}

In Nigeria, maize (Zea mays L.,) is annually cultivated in about 5.33 million hectares of land yielding about 7.5 million tons of maize [1]. It is one of the most important cereal crops in sub-Sahara Africa. According to Food and Agricultural Organization [2] data, 872 million tons of maize was produced world-wide in the year 2012. The United States of America was the largest producer, having 31.4\% of the world production and Africa produced $8 \%$ [3]. Nigeria was the second producer of maize in Africa in the year 2012 with 9.41 million tons, South Africa being the largest producer with production of 11.8 million tons.

Maize, also referred to as corn is an important cereal grown in Nigeria because of its wide use and important role in the diet of majority of people. The maize grain could be used to produce variety of dishes that require preliminary preparations such as soaking in water, dehulling, fermentation, germination, drying and milling to produce fine flour and grits. The treatment used depends on the product to be produced. Hydration through soaking is the most common preliminary process applied to cereals, legumes and grains during the production of various cereals, legumes and grains based food product such as thin porridge pap (ogi) [4], alcoholic and non-alcoholic beverages [5,6] as well as an important operation in rice parboiling [7].

During the soaking of food materials, liquid water is progressively absorbed. The extent of water absorption or the amount of water absorbed into the food material during soaking depends primarily on the soaking water temperature, time, initial moisture content, variety of the seeds, soaking duration, acidity level of the water and physicochemical properties (such as seed structure, size etc) of the food material [8-13].

The understanding of water absorbing characteristics is considered theoretically and practically important in the food processing industry $[14,15]$. Several investigations have been conducted on the water absorbing characteristics of various foods such as soybean, spaghetti and rice [16-18]. Furthermore, investigations on how temperature, $\mathrm{pH}$, physiochemical properties and other nutritional composition affect water absorption capacities of grains and beans have been conducted. Researchers have demonstrated that increasing the temperature of the soaking medium is an effective way to accelerate water uptake by various seeds and hence, shorten the soaking time $[19,20]$. Also, many studies have reported the influence of temperature on moisture diffusivity into soybean, amaranth grains and maize kernels, respectively [14,21,22]. However, effects of varietal variations and processing variables on the rate of water uptake and moisture diffusivity in some cereals grown in Nigeria, such as maize and its processed form have not been clearly established.

Thus, from a processing and engineering point of view, it is highly desirable and of practical importance to know how fast the absorption of water can be accomplished, how it will be affected by processing variables [23], and also, how one can predict the soaking time under given conditions. Hence, quantitative data on the effect of processing variables are necessary for practical applications to optimize and characterize the soaking conditions, design food processing equipment and predict water absorption as a function of time and temperature $[15,20,24]$.This, however, depends on the availability of moisture diffusivity data for the variety being considered [25].

It is therefore, the purposeof this study to show how temperature

*Corresponding author: Agarry SE, Department of Chemical Engineering, Ladoke Akintola University of Technology, Ogbomoso, Nigeria, Tel: 234-8067624977; E-mail: sam_agarry@yahoo.com

Received March 01, 2014; Accepted May 13, 2014; Published May 28, 2014

Citation: Agarry SE, Afolabi TJ, Akintunde TTY (2014) Modelling the Water Absorption Characteristics of Different Maize (Zea Mays L.) Types during Soaking. J Food Process Technol 5: 326. doi:10.4172/2157-7110.1000326

Copyright: (C) 2014 Agarry SE, et al. This is an open-access article distributed under the terms of the Creative Commons Attribution License, which permits unrestricted use, distribution, and reproduction in any medium, provided the original author and source are credited. 
and variety affect the water absorption characteristics of Nigerian maize type and its processed form.

\section{Materials and Methods}

Dent corn (white and yellow), corn flour (white and yellow), popcorn and sweet corn were obtained from the International Institute of Tropical Agriculture (IITA), Ibadan, Nigeria. Grains were manually selected to remove foreign material and damaged ones prior to experiment. The selected grains were kept in nylon bags. The initial moisture content of maize was determined by oven drying method of whole kernels in triplicate at $120^{\circ} \mathrm{C}$ for $8 \mathrm{~h}$ and expressed on dry basis.

The principal dimensions (viz. length, breadth and thickness) were measured with a vernier caliper having least count of $0.02 \mathrm{~mm}$ [23]. The shape of the maize is irregular and the nearest shape that can be assumed for the maize is a sphere. Thus, the volume of 50 kernels was measured in triplicate by water displacement in a graduated cylinder. Average volume was equated to the volume of a spherical object as given in Eq. (1), and the equivalent radius $\mathrm{R}$ was obtained [25].

$$
v=\frac{4 \pi R^{3}}{3}
$$

The volume-surface ratio $(v / s)$ was calculated from Eq. (2) [23]:

$$
\frac{v}{s}=\frac{v^{1 / 3} \phi}{4.836}
$$

Where $\phi$ is the sphericity

The sphericity of the grains was computed using Eq. (3) [26]:

$$
\phi=\frac{(L B T)^{1 / 3}}{L}
$$
$(\mathrm{mm})$.

Where $B$ is the length ( $\mathrm{mm}), B$, breadth $(\mathrm{mm})$ and $T$, thickness

\section{Water soaking experiment}

Moisture content changes of the six species of maize during soaking in waterwere measured at four different water temperatures $\left(30,40,50\right.$, and $\left.60^{\circ} \mathrm{C}\right)$. Five replicates of $10 \pm 0.5 \mathrm{~g}$ samples weighed with a digital balance were eachplaced in a net and soaked in a water bath. The samples were removed fromthe water bath at each predetermined time, and blotted with tissue paper toremove residual liquid on the surface of the kernels [25], and then reweighed. These operations were conducted at eachpredetermined time until the test was completed. The increase in sample massduring soaking in water was considered to be an increase in sample moisturecontent [27].

The initial moisture content of the different maize species was determined by oven drying method in triplicate at $103^{\circ} \mathrm{C}$ for $24 \mathrm{~h} \mathrm{[28]}$ and expressed as $\mathrm{kg} / \mathrm{kg}(\mathrm{db})$. The moisture gain was calculated from the gain in weight of the sample to an accuracy of $0.001 \mathrm{~g}$ using digital balance.

\section{Modelling of water absorption}

Modeling the process of water absorption by agricultural seeds helps in understanding the dynamic and kinetic of this process and this knowledge is valuable for proper management of their soaking processes. A number of equations have been proposed to describe the water absorption characteristics of food materials. An equation was developed by Peleg [29] to model the mode of water absorption by food materials. It is a two-way parameter, non-exponential, empirical equation which has been reported to describe the water uptake in food materials especially that of soaked cereals and leguminous food grains accurately [11,30-34]. The Peleg equation is:

$$
M_{t}=M_{o}+\frac{t}{K_{1}+K_{2} t}
$$

where $M_{t}$ is moisture content (\%) at time $\mathrm{t}(\mathrm{h}), M_{o}$ is initial moisture content $(\%), \mathrm{K}_{1}$ is the Peleg rate constant $\left(\mathrm{h} \%^{-1}\right)$, and $\mathrm{K}_{2}$ is the Peleg capacity constant $\left(\%^{-1}\right)$. In Eq. (4), " \pm "becomes " + " if the process is absorption or adsorption and "-" if the process is drying or desorption.

$$
\begin{aligned}
& \text { If } t=0 \\
& \frac{d M_{t}}{d t}=\frac{1}{K_{1}}
\end{aligned}
$$

As soaking proceeds, i.e. $t \rightarrow \infty$, Eq.(1) gives the relation between equilibrium moisture content $\left(M_{e}\right)$ and $K_{2}$

$$
M_{e}=M_{o}+\frac{1}{K_{2}}
$$

Values of $K_{1}$ and $K_{2}$ are obtained from the linearized form of the equation.

Furthermore, moisture diffusion into the grains is primarily caused by concentration gradient. This gradient tends to move the water molecules to equalize concentration. Becker [35], using Fick's law of molecular diffusion, proposed the following mathematical model (Eq. (7)) for diffusion in solids of arbitrary shape to correlate the moisture gain by wheat kernel during soaking in water

$$
M R=\frac{m_{s}-m}{m_{s}-m_{o}}=1-\frac{2}{\sqrt{\pi}} X+B X^{2}
$$

Where $M R$ is moisture ratio, $m, m_{o}$ and $m_{s}$ are average moisture contents at any given soaking duration, initial moisture content and moisture content at the bounding surface respectively. For small values of X, Eq. (7) can be approximated to Eq. (8):

$$
1-M R=\left(\frac{2}{\sqrt{\pi}}\right) X
$$

Where

$$
X=(s / v) \sqrt{D \theta}
$$

in which $s / v$ is surface to volume ratio

Combining Eqs. (7) - (9), we get

$$
m-m_{o}=\alpha_{b} \sqrt{\theta}
$$

Where

$$
\alpha_{b}=\left(\frac{2}{\sqrt{\pi}}\right)\left(m_{s}-m_{o}\right)(s / v) \sqrt{D}
$$




$$
D=\frac{\alpha_{b} \sqrt{\pi}}{\left[2\left(m_{s}-m_{o}\right)(s / v)\right]^{2}}
$$

In Eq. (12), $m_{o}$ and $m_{s}$ are constants for a particular type of grain and the ratio of volume-to-surface area $(s / v)$ may be taken as constant irrespective of moisture content [35,53]. A plot of $\left(m_{s}-m_{o}\right)$ with $\sqrt{\theta}$ would give a straight line of slope $\left(\alpha_{b}\right)$ for a particular water temperature of soaking (Eq. 10). At different water temperatures the slope $\left(\alpha_{b}\right)$ would vary. Moisture diffusivity, $\mathrm{D}$, can be determined at different temperatures using different values in Eq. (12).

\section{Results and Discussion}

The physical properties of the maize kernels are listed in Table 1.

\section{Water absorption curves of six maize types}

The time variations in water absorption by six maize types at different temperatures are shown in Figure 1(a-f). The maize samples exhibited the typical water absorption characteristic as previously described for other food materials [11,22,29,31-33]. There is an initial very rapid rate of water absorption which was later followed by a slower rate in the later stages as the Saturation Moisture Content (SMC) was approached at all four temperatures. SMC was attained at a higher time $(11 \mathrm{~h})$ for soaking water temperature of $30^{\circ} \mathrm{C}$ but reduced as the water temperature increased for all the maize types studied. This is because temperatures above the gelatinization temperature of starch (approximately $60^{\circ} \mathrm{C}$ ) can result in starch gelatinization and protein denaturation [36]. Also, it was observed that the water absorption rate was affected by soaking temperature. The water absorption rate increased with increase in soaking temperature as this is due to increased water diffusion rate. Similar observations have been reported $[11,13,22,27,30,34,37-40]$. However, the rates of increment between the initial and final soaking temperatures were not the same for the different maize types. This could be as a result of the difference in nutritional composition of the maize types considered. Addo et al. [22] made similar observation when they studied the water absorption characteristics of maize (Obatanpa and Mamaba) as well as Shittu et al. [11], and Ali et al. [41] when they studied the water absorption characteristics of rice. The soaking water temperature and concentration of starch in food material determines starch behavior in water $[13,22]$. Generally, starch grains have very little uptake of water at room temperature and their swelling power is also small. As the temperature increases, the water uptake increases and starch granules collapse leading to solubilization of amylose and amylopectin to form a colloidal solution. Thus, the increase in water absorption as temperature increased. At each soaking temperature, sweet corn had a relatively higher moisture gain (water absorptivity) than all the maize varieties used in this study. This is relatively followed by white corn flour, yellow corn flour, dent white corn, popcorn and dent yellow corn, respectively. This observed difference in the water absorption capacity of the different maize variety may probably be due to difference in their size and initial water content, respectively. Sopade and Obekpa [30] and Tang et al. [42] reported that the smaller a seed is, the larger is its water absorption capacity because of the increased specific surface area for absorption. This phenomenon was observed in this study for four of the varieties (sweet corn, white flour, yellow flour and dent yellow corn) which had different size and initial water content. Sweet corn, which has smaller size and lower initial water content as compared to white corn flour, yellow corn flour and dent yellow corn, had a higher uptake of water. While dent white corn and popcorn which has very similar smallest size $(3.66 \mathrm{~mm} / 3.69 \mathrm{~mm})$ and highest initial water content $(10.92 \%$ $110.96 \%)$ showed no significant difference in their maximum water uptake at the temperature of $50^{\circ} \mathrm{C}$ and $60^{\circ} \mathrm{C}$, respectively. More also, at each of the soaking water temperature, the maximum water uptake by the dent white corn and popcorn was lower than that of white flour, yellow flour and sweet corn, respectively. That is, white corn flour, yellow corn flour and sweet corn which are relatively larger in size with lower initial water content had higher water absorption capacity than dent white corn and popcorn with smaller size and higher initial water content. A similar observation has been reported for Obatanpa and Mamaba maize type [22]. This observation may probably be due to the difference in severity of disorderliness arising from the different levels of temperature used as a result of differences in nutritional composition [22]. Also, this observation could indicate a strong possibility of white flour, yellow flour and sweet corn having higher starch content than the rest of the maize types. Addo et al. [22] observed similar behavior when they reported that the higher starch content in Obatanpatype of maize was responsible for the higher uptake of water even though Obatanpa seed is larger than Mamaba maize type. Nevertheless, the results presented suggest that maximum water absorption is shown by smaller grains with lower initial water content. Knowledge of water absorption capacity and the required corresponding time to attain it is very pertinent in the processing of food. The chemical composition of food materials contributes significantly to its water absorption process $[43,44]$. The chief components of food materials that absorb water are the protein and carbohydrates while proteins have a higher capacity to absorb water more than carbohydrates. Hence, at the same temperature, grain-seeds that have higher protein content would have higher water absorption capacity and probably faster absorption rates. High water absorption capacity is desirable for food grain subjected to processing operations such as wet milling [13]. This is because when grain-seeds approach water saturation it reduces the mechanical stress required for wet milling [45] as well as enhances the extraction of important constituents such as starch in cereal grains. Therefore, it will be more efficient to soak maize grains at high soaking temperature of $60^{\circ} \mathrm{C}$ during maize processing into oat-like or slurry form and other forms that require wet milling.

\section{Water absorption modelling}

Fitting of Peleg's model: The experimental data were fitted to Peleg's model (Eq. (4)) as shown in Figure 2(a-f) and the estimated Peleg's constants are presented in Table 2. The determination coefficient $\left(\mathrm{R}^{2}\right)$ varied from 0.9858 to 0.9997 indicating a good fit to the experimental data. This suggests the suitability of Peleg's model for describing the water absorption behavior of six maize types in the

\begin{tabular}{|c|c|c|c|c|c|c|}
\hline Parameter & Dent White Corn & Dent Yellow Corn & White Corn Flour & Yellow Corn Flour & Sweet Corn & Pop Corn \\
\hline Moisture Content (\%db) & $10.92 \pm 0.1$ & $10.94 \pm 0.1$ & $10.65 \pm 0.1$ & $10.88 \pm 0.1$ & $10.49 \pm 0.1$ & $10.96 \pm 0.1$ \\
\hline Length $(\mathrm{mm})$ & $11.36 \pm 0.1$ & $8.75 \pm 0.1$ & $10.39 \pm 0.1$ & $10.00 \pm 0.1$ & $10.81 \pm 0.1$ & $7.74 \pm 0.1$ \\
\hline Width (mm) & $9.42 \pm 0.1$ & $8.75 \pm 0.1$ & $8.75 \pm 0.1$ & $9.34 \pm 0.1$ & $8.13 \pm 0.1$ & $5.54 \pm 0.1$ \\
\hline Thickness (mm) & $3.69 \pm 0.1$ & $4.55 \pm 0.1$ & $3.88 \pm 0.1$ & $4.23 \pm 0.1$ & $3.86 \pm 0.1$ & $3.66 \pm 0.1$ \\
\hline $\mathrm{R}(\mathrm{mm})$ & 6.7 & 6.6 & 6.7 & 6.6 & 4.5 & 4.6 \\
\hline
\end{tabular}

Table 1: Physical properties of six maize types. 

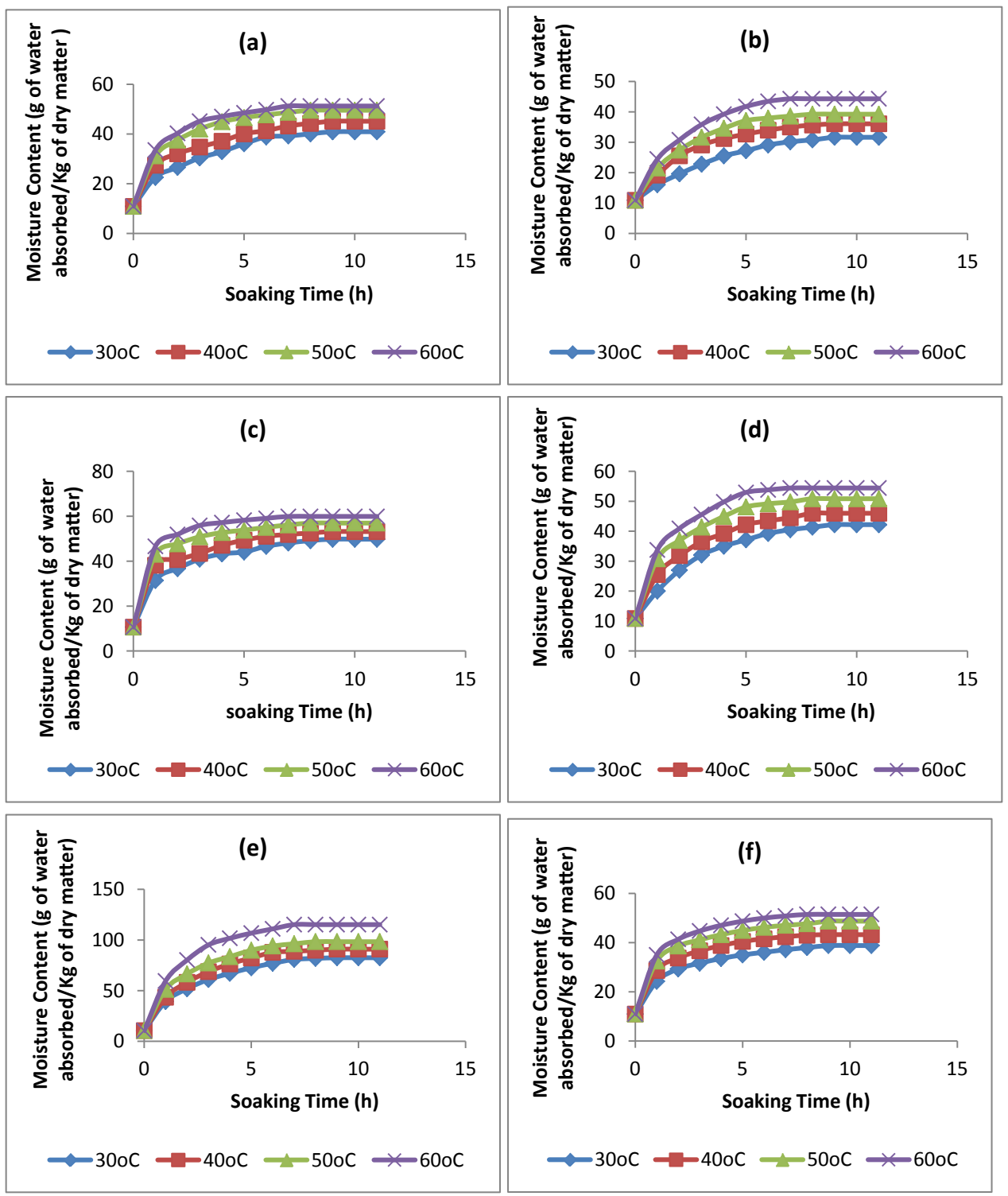

Figure 1: Water absorption characteristics for (a) dent white corn (b) dent yellow corn (c) white flour corn (d) yellow flour corn (e) sweet corn (f) popcorn.

hydration temperatures investigated (i.e. 30 to $60^{\circ} \mathrm{C}$ ). From Table 2, it could be seen that as the hydration temperature increased from 30 to $60^{\circ} \mathrm{Cfor}$ each of the six maize types, the Peleg rate constant $\mathrm{K}_{1}$ generally decreased significantly, suggesting an increase in the initial water absorption rate. That is, $\mathrm{K}_{1}$ is a constant related to mass transfer rate, e.g., the lower the $\mathrm{K}_{1}$, the higher the initial water absorption rate and its sensitivity to temperature is indicative of the positive effect of increased temperature on the rate of water absorbed [13]. Similar observation has been reported $[13,33,46-48]$.This temperature sensitivity was more pronounced at water soaking temperature of $60^{\circ} \mathrm{C}$ where the $\mathrm{K}_{1}$ value was lowest (Table 2). The initial water absorption (hydration) rate as determined by $\mathrm{K}_{1}$ values was highest at the soaking temperature of $60^{\circ} \mathrm{C}$ which is consistent with the hydration curves of Figure $1(\mathrm{a}-\mathrm{f})$. In addition, for each of the six maize varieties, the Peleg capacity constant $\mathrm{K}_{2}$ also decreased as the temperature of the soaking water increased. Similar observation has been reported for Hazelnut kernel and whole Hazelnut [49], Acha [13], Pearl millet grains and Hungry rice [39].
Nevertheless, there are mixed reports on the effect of temperature on water absorption capacity of food materials, namely on $\mathrm{K}_{2}$, and this depends on type of material and if soluble solids loss during soaking is considered in the calculation of moisture content of samples [50,51]. Sopade and Obekpa [30]; Sopade et al. [31]; Hung et al. [32]; Sopade et al. [46]; Quicazán et al. [48]; Abu-Ghannam and McKenna [50]; Maharaj and Sankat [33], in their previous water absorption studies using the Peleg model had reported that there was no effect of temperature on $\mathrm{K}_{2}$. While Turhan et al. [47] reported an increase in $\mathrm{K}_{2}$ as temperature increased during Chickpea water absorption studies. $\mathrm{K}_{2}$ is a constant related to maximum water absorption capacity, i.e., the lower the $\mathrm{K}_{2}$, the higher the water absorption capacity [13,30,47]. Thus, soaking each of the six varieties of maize at higher temperatures results in increased absorption capacity and higher equilibrium water content of hydration as indicated by $\mathrm{K}_{2}$ values and as shown in Figure $1(\mathrm{a}-\mathrm{f})$. The hydration equilibrium water content was determined using Eq. (6) and the predicted values are shown in Table 2. The observed SMC 

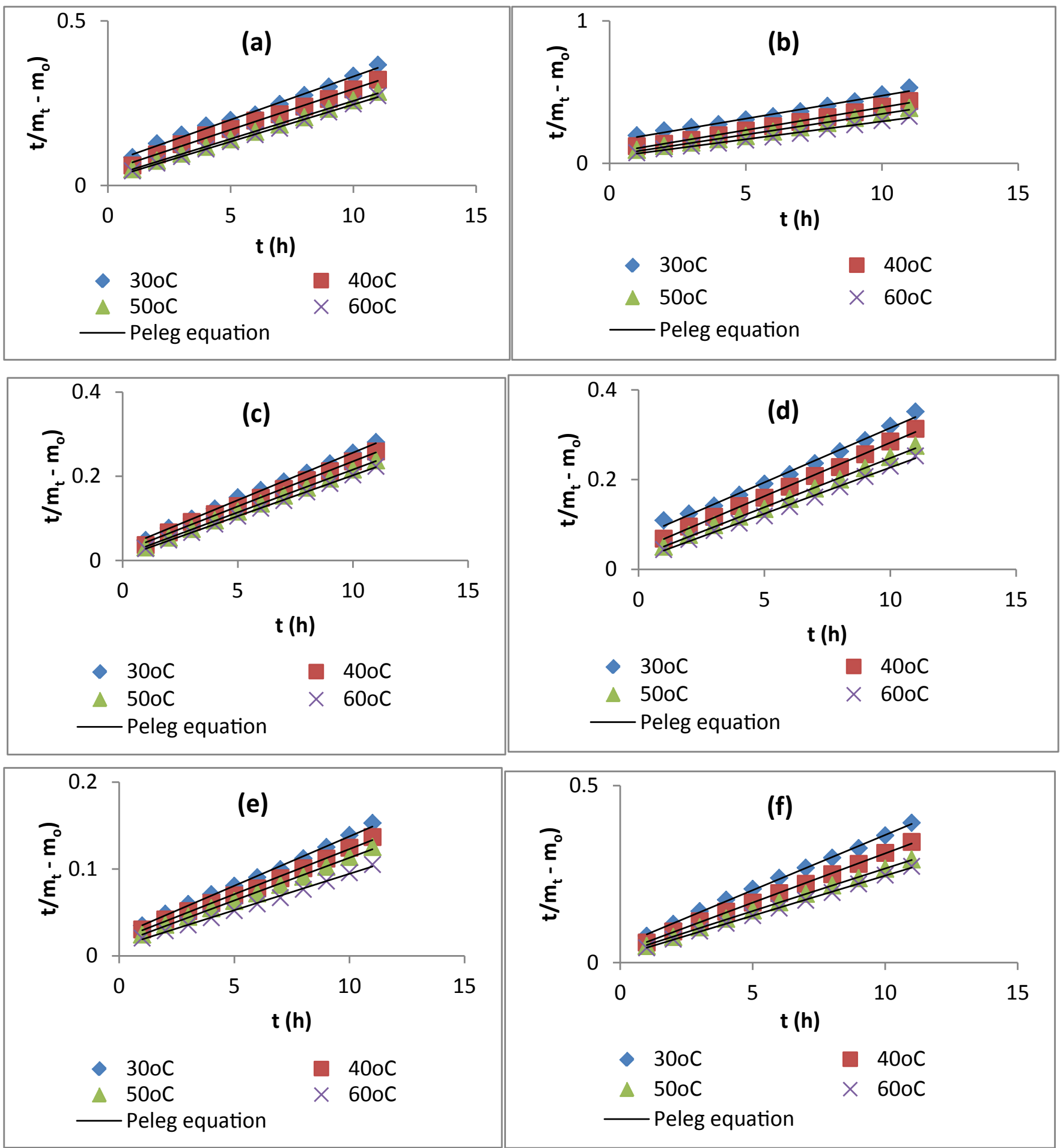

Figure 2: Fitted Peleg equation to the water absorption data for (a) dent white corn (b) dent yellow corn (c) white flour corn (d) yellow flour corn (e) sweet corn (f) popcorn.

values were taken as the asymptotes of the rehydration curve in Figure $1(a-f)$. There is no significant difference in the values of the observed and predicted equilibrium moisture content that was determined by experimental or predictive methods based on curvilinear experimental data only and Peleg's equation. This corroborates the observations of Maharaj and Sankat [33] and Tunde-Akintunde[13].
Fitting of Becker's model: The experimental data were also fitted to Becker'smodel (Eq. (7)) as shown in Figure 3(a-f) and the estimated diffusion coefficients and determination coefficients $\left(\mathrm{R}^{2}\right)$ are presented in Table 3. The determination coefficient varied from 0.9618 to 0.9984 also indicating a good fit to the experimental data. Consequently, this also suggests the suitability of Becker's model for describing the water 
Page 6 of 9

\begin{tabular}{|c|c|c|c|c|c|c|}
\hline Maize Type & $\begin{array}{c}\text { Temperature } \\
\left({ }^{\circ} \mathrm{C}\right)\end{array}$ & $K_{1} \times 10^{-2}\left(\mathrm{~h}^{-1}\right)$ & $K_{2} \times 10^{-2}(\% \mathrm{DM})$ & Observed SMC & Predicted SMC & $\left(R^{2}\right)$ \\
\hline \multirow{4}{*}{ Dent White Corn } & 30 & 6.79 & 2.63 & 40.93 & 48.94 & 0.9932 \\
\hline & 40 & 4.54 & 2.48 & 45.15 & 51.24 & 0.9960 \\
\hline & 50 & 2.58 & 2.31 & 49.58 & 54.21 & 0.9990 \\
\hline & 60 & 2.03 & 2.26 & 51.27 & 55.17 & 0.9989 \\
\hline \multirow{4}{*}{ Dent Yellow Corn } & 30 & 15.29 & 3.22 & 31.65 & 42.00 & 0.9858 \\
\hline & 40 & 7.34 & 3.20 & 36.08 & 42.19 & 0.9908 \\
\hline & 50 & 5.58 & 2.92 & 39.24 & 45.19 & 0.9934 \\
\hline & 60 & 3.10 & 2.63 & 44.30 & 48.96 & 0.9934 \\
\hline \multirow{4}{*}{ White Flour } & 30 & 3.06 & 2.25 & 49.79 & 55.09 & 0.9985 \\
\hline & 40 & 2.16 & 2.14 & 53.16 & 57.38 & 0.9979 \\
\hline & 50 & 1.27 & 2.03 & 56.96 & 59.91 & 0.9996 \\
\hline & 60 & 0.82 & 1.94 & 59.92 & 62.20 & 0.9997 \\
\hline \multirow{4}{*}{ Yellow Flour } & 30 & 7.25 & 2.43 & 42.19 & 52.03 & 0.9928 \\
\hline & 40 & 4.39 & 2.38 & 45.99 & 52.90 & 0.9975 \\
\hline & 50 & 2.90 & 2.19 & 50.84 & 56.54 & 0.9978 \\
\hline & 60 & 2.14 & 2.06 & 53.38 & 59.42 & 0.9969 \\
\hline \multirow{4}{*}{ Sweet Corn } & 30 & 2.38 & 1.14 & 82.49 & 98.21 & 0.9969 \\
\hline & 40 & 1.90 & 1.04 & 90.93 & 106.64 & 0.9963 \\
\hline & 50 & 1.46 & 0.98 & 98.31 & 112.53 & 0.9979 \\
\hline & 60 & 1.06 & 0.84 & 115 & 129.54 & 0.9975 \\
\hline \multirow{4}{*}{ Popcorn } & 30 & 4.87 & 3.12 & 38.82 & 43.01 & 0.9988 \\
\hline & 40 & 3.04 & 2.78 & 42.41 & 46.93 & 0.9993 \\
\hline & 50 & 2.53 & 2.40 & 48.73 & 52.63 & 0.9994 \\
\hline & 60 & 1.93 & 2.26 & 51.48 & 55.21 & 0.9975 \\
\hline
\end{tabular}

Table 2: Estimated values of Peleg's constants and determination coefficients $\left(R^{2}\right)$ obtained from the fitting of Peleg's model to the water absorption data for different maize types.

absorption or moisture diffusivity behaviour of six maize types in the hydration temperatures investigated (i.e. 30 to $60^{\circ} \mathrm{C}$ ). The SMCs $\left(\alpha_{b}\right)$ used in Eq. (7) are listed in Table 2 for each maize type and soaking temperature. The water absorption rates for the six types of maize are shown in Figure 3(a-f). From Table 3, the diffusion coefficients for sweet corn $\left(10.6-13.5 \times 10^{-11} \mathrm{~m}^{2} / \mathrm{s}\right)$ are comparatively higher than the corresponding values for other maize types. This is relatively followed by the values for white corn flour $\left(6.74-8.88 \times 10^{-11} \mathrm{~m}^{2} / \mathrm{s}\right)$, yellow corn flour $\left(5.27-7.09 \times 10^{-11} \mathrm{~m}^{2} / \mathrm{s}\right)$, popcorn $\left(4.44-5.79 \times 10^{-11} \mathrm{~m}^{2} / \mathrm{s}\right)$, dent white corn $\left(4.25-5.69 \times 10^{-11} \mathrm{~m}^{2} / \mathrm{s}\right)$ and dent yellow corn $(3.28-4.68$ $\times 10^{-11} \mathrm{~m}^{2} / \mathrm{s}$ ), respectively. This could be attributed to the differences in the kernel characteristics of the different maize types [52]. Verma and Prasad [23] reported that the moisture diffusivity of 'Kisan' maize varied from $1.108 \times 10^{-11}$ to $3.313 \times 10^{-11} \mathrm{~m}^{2} / \mathrm{s}$ in the temperature range of $30-60^{\circ} \mathrm{C}$. Haros et al. [52] also reported diffusion coefficient ranges of $2.499 \times 10^{-11}$ to $6.498 \times 10^{-11} \mathrm{~m}^{2} / \mathrm{s}, 2.499 \times 10^{-11}$ to $6.804 \times 10^{-11} \mathrm{~m}^{2} / \mathrm{s}$, and $1.888 \times 10^{-11}$ to $4.999 \times 10^{-11} \mathrm{~m}^{2} / \mathrm{s}$ for dent, semident and flint maize hybrids during plain water soaking at a temperature range of $45-65^{\circ} \mathrm{C}$. Addo et al. [22] also reported diffusion coefficient ranges of $7.31 \times 10^{-12}$ to $9.33 \times 10^{-12} \mathrm{~m}^{2} / \mathrm{s}$ for Obatanpa and $6.30 \times 10^{-12}$ to $8.25 \times 10^{-12} \mathrm{~m}^{2} / \mathrm{s}$ ) for Mamaba, respectively.

Temperature dependence of moisture diffusivity: The temperature dependence of the diffusion coefficient for the maize types was expressed by the Arrhenius-type of equation (Eq. (13)) [22,53]:

$$
D=D_{o} \exp \left(-\frac{E_{a}}{R T}\right)
$$

Where $\mathrm{D}$ is diffusion coefficient $\left(\mathrm{m}^{2} / \mathrm{s}\right) ; \mathrm{D}_{\mathrm{o}}$, diffusion constant $\left(\mathrm{m}^{2} / \mathrm{s}\right) ; \mathrm{E}_{\mathrm{a}}$, activation energy $(\mathrm{kJ} / \mathrm{mol}) ; \mathrm{R}$, gas constant $\left(8.314 \times 10^{-3} \mathrm{KJ} /\right.$ $(\mathrm{k} \mathrm{mol})$ ); and $\mathrm{T}$, temperature $(\mathrm{K})$.
Eq. (13) shows that the relationship between the diffusion coefficients and the reciprocal of the absolute temperature was linear on a semi-logarithmic plot. Figure 4(a-f) shows the Arrhenius relation for the diffusion coefficients of the six maize types. Arrhenius equation was sufficient to describe the temperature effect on the moisture absorption, as the regression coefficient was 0.91or higher (Table 3). The activation energy values were $8.17,9.59,7.83,8.45,6.61$ and $8.01 \mathrm{~kJ} / \mathrm{mol}$ for dent white corn, dent yellow corn, white corn flour, yellow corn flour, sweet corn and popcorn, respectively (Table 3 ). The activation energy values obtained were comparatively lower than the reported values of $35069.55 \mathrm{~kJ} / \mathrm{kg}$ mol K for Kisan maize [23], $45.75 \mathrm{~kJ} /$ mol for 'Hi-starch' maize [53], 28.66, 31.69 and $34.15 \mathrm{~kJ} / \mathrm{mol}$ for ' $\mathrm{K}-4$ ' hybrid popcorn, 'K-1859' hybrid maize and 'Gold Rash' sweet maize [54], $19.25 \mathrm{~kJ} / \mathrm{mole}$ for husk, $31.50 \mathrm{~kJ} / \mathrm{mole}$ for paddy and $37.32 \mathrm{~kJ} / \mathrm{mole}$ for brown rice [55], $44.0 \mathrm{~kJ} / \mathrm{mol}$ for wheat and $45.9 \mathrm{~kJ} / \mathrm{mol}$ for barley [27]. However, the values for dent white corn, dent yellow corn, white corn flour, yellow corn flour and popcorn are relatively higher than the values of $6.54 \mathrm{~kJ} / \mathrm{mol}$ and $6.82 \mathrm{~kJ} / \mathrm{mol}$ for Obatanpa and Mamaba maize varieties [22] and $0.35 \mathrm{~kJ} / \mathrm{mol}$ for acha [13]. Nevertheless, the lower value for the six maize types suggests that their rate of water absorption is faster when compared to other cereals mentioned with higher activation energy. These lower values may probably be due to their small particle size and their high starch content.

\section{Conclusion}

The period of reaching saturation or equilibrium moisture content during water soaking for dent white corn, dent yellow corn, white corn flour, yellow corn flour, sweet corn and popcorn was reduced from $11 \mathrm{~h}$ to $8 \mathrm{~h}$ by the increase in water soaking temperature from 30 to $60^{\circ} \mathrm{C}$. The water absorption behavior of dent white corn, dent yellow corn, white corn flour, yellow corn flour, sweet corn and popcorn at different water soaking temperatures were adequately modelled by Peleg's model and 

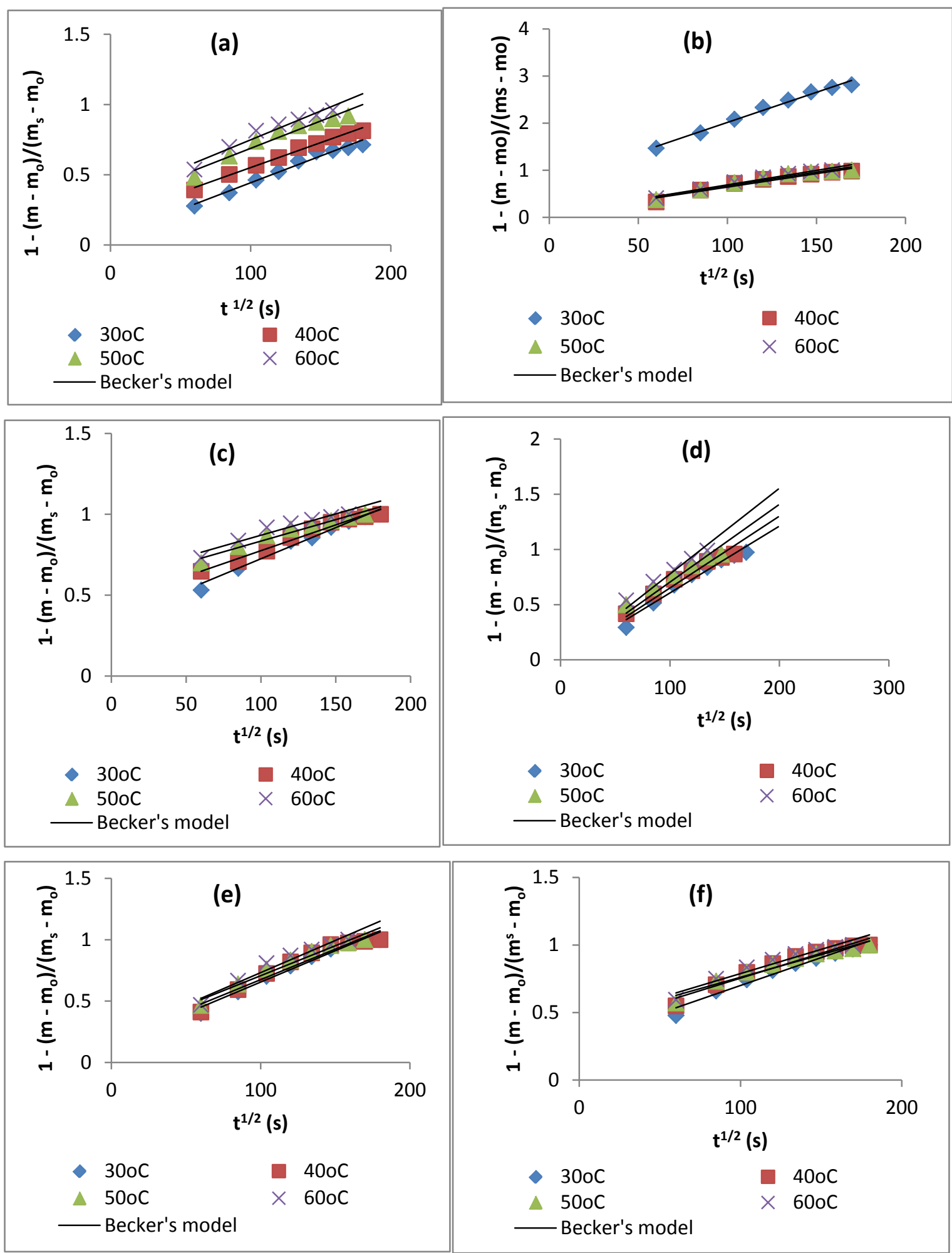

Figure 3: Fitted Becker's model to the water absorption data for (a) dent white corn (b) dent yellow corn (c) white flour corn (d) yellow flour corn (e) sweet corn (f) popcorn.

Becker's model (Fick's law of diffusion), respectively. An increase in the water soaking temperature resulted in a decrease in Peleg's $K_{1}$ constant for each of the maize variety. The initial hydration rate, which is determined by the inverse of $\mathrm{K}_{1}$, increased with increase in water soaking temperature. The Peleg's $\mathrm{K}_{2}$ constant increased with decrease in water soaking temperature. Thus the water absorption capacities of 


\begin{tabular}{|c|c|c|c|c|}
\hline Maize Type & $\begin{array}{l}\text { Temperature } \\
\left({ }^{\circ} \mathrm{C}\right)\end{array}$ & $\begin{array}{l}\text { Diffusion Coefficient } \\
\left(D \times 10^{-11}\right)\left(\mathrm{m}^{2} / \mathrm{s}\right)\end{array}$ & $\mathrm{R}^{2}$ & $\mathrm{E}_{\mathrm{a}}(\mathrm{kJ} / \mathrm{mol})$ \\
\hline \multirow{4}{*}{$\begin{array}{l}\text { Dent White } \\
\text { Corn }\end{array}$} & 30 & 4.25 & 0.9783 & \multirow{4}{*}{8.17} \\
\hline & 40 & 4.42 & 0.9984 & \\
\hline & 50 & 4.95 & 0.9876 & \\
\hline & 60 & 5.69 & 0.9848 & \\
\hline \multirow{4}{*}{$\begin{array}{l}\text { Dent Yellow } \\
\text { Corn }\end{array}$} & 30 & 3.28 & 0.9881 & \multirow{4}{*}{9.59} \\
\hline & 40 & 3.47 & 0.9727 & \\
\hline & 50 & 3.85 & 0.9928 & \\
\hline & 60 & 4.68 & 0.9768 & \\
\hline \multirow{4}{*}{ White Flour } & 30 & 6.74 & 0.9839 & \multirow{4}{*}{7.83} \\
\hline & 40 & 7.65 & 0.9898 & \\
\hline & 50 & 8.38 & 0.9851 & \\
\hline & 60 & 8.88 & 0.9839 & \\
\hline \multirow{4}{*}{ Yellow Flour } & 30 & 5.27 & 0.9755 & \multirow{4}{*}{8.45} \\
\hline & 40 & 5.70 & 0.9916 & \\
\hline & 50 & 6.38 & 0.9958 & \\
\hline & 60 & 7.09 & 0.9625 & \\
\hline \multirow{4}{*}{ Sweet Corn } & 30 & 10.6 & 0.9860 & \multirow{4}{*}{6.61} \\
\hline & 40 & 11.2 & 0.9895 & \\
\hline & 50 & 12.0 & 0.9918 & \\
\hline & 60 & 13.5 & 0.9949 & \\
\hline \multirow{4}{*}{ Popcorn } & 30 & 4.44 & 0.9884 & \multirow{4}{*}{8.01} \\
\hline & 40 & 4.73 & 0.9618 & \\
\hline & 50 & 5.51 & 0.9968 & \\
\hline & 60 & 5.79 & 0.9883 & \\
\hline
\end{tabular}

Table 3: Estimated values of diffusion coefficients and determination coefficients $\left(R^{2}\right)$ obtained from the fitting of Becker's model to the water absorption data for different maize types and their activation energies $\left(E_{a}\right)$.

the six types of maize or their saturation moisture content increased with increase in water soaking temperature since both are determined from the inverse of Peleg's $\mathrm{K}_{2}$ constant. Also, for each of the six maize type, the water diffusion coefficients increased with increase in water soaking temperature and this varied from 10.6 to $13.5 \times 10^{-11} \mathrm{~m}^{2} / \mathrm{s}$ for sweet corn, 6.74 to $8.88 \times 10^{-11} \mathrm{~m}^{2} / \mathrm{s}$ ) for white flour, 5.27 to $7.09 \times 10^{-11}$ $\mathrm{m}^{2} / \mathrm{s}$ for yellow flour, 4.44 to $5.79 \times 10^{-11} \mathrm{~m}^{2} / \mathrm{s}$ for popcorn, 4.25 to 5.69 $\times 10^{-11} \mathrm{~m}^{2} / \mathrm{s}$ for dent white corn and 3.28 to $4.68 \times 10^{-11} \mathrm{~m}^{2} / \mathrm{s}$ for dent yellow corn, respectively, within the temperature range of $30-60^{\circ} \mathrm{C}$. An Arrhenius-type of equation described the strong effect of temperature on the diffusion coefficient with activation energy values of $8.17,9.59$, $7.83,8.45,6.61$ and $8.01 \mathrm{~kJ} / \mathrm{mol}$ for dent white corn, dent yellow corn, white flour, yellow flour, sweet corn and popcorn, respectively. Water soaking of dent white corn, dent yellow corn, white corn flour, yellow corn flour, sweet corn and popcorn at $60^{\circ} \mathrm{C}$ is recommended because of the increased absorption capacity and higher saturation moisture content of hydration obtained at this temperature and subsequently the mechanical stress required for wet milling is reduced at this temperature.

\section{References}

1. FAO (1992) Maize in Human Nutrition. Food and Agriculture Organisation of the United Nations, Rome.

2. FAOSTAT (2012) Agricultural data. FAO, Rome.

3. IITA (2002) Maize.

4. Apena A, Chinweike-Umeh SN, Abaelu AM (2006) Evaluation of improved Ogi (Apik) with potential for the control of diarrhoea. Nigerian Food J 24: 180-185.

5. Ayo A, Obeya MC (2004) Effect of different cultivars of millet on the quality of "Kunun- zaki". A millet-based non-alcoholic beverage. J Food Sci Technol 41 394-397.

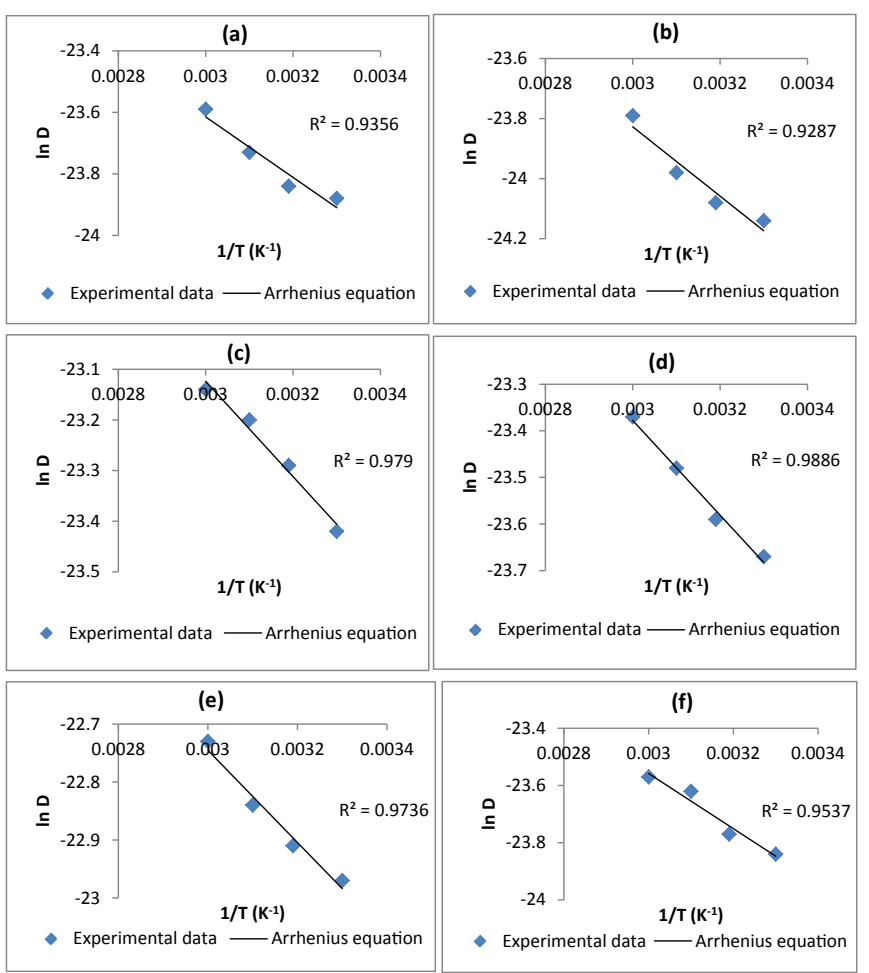

Figure 4: Temperature dependence of moisture diffusivity for (a) dent white corn (b) dent yellow corn (c) white flour corn (d) yellow flour corn (e) sweet corn (f) popcorn.

6. Igyor MA, Ainahu CC, Omale Y (2006) Chemical and microbiological characteristics of burukutu-a traditional beer. Nigerian Food J 24: 86-91.

7. Engels C, Hendrickx M, De Samblanx S, De Gryze I, Tobback P (1986) Modelling water diffusion during long-grain rice soaking. J Food Eng 5: 55-73.

8. Hsu KH, Kim CJ, Wilson LA (1983) Factors affecting water uptake of soybean during soaking. Cereal Chem 60: 208-211.

9. Singh BPN, Kulshrestha SP (1987) Kinetics of water sorption by soybean and pigeon-pea grains. J Food Sci 52: 1538-1541.

10. Karapantsios TD, Sakonidou EP, Raphaelides SN (2002) Water dispersion kinetics during starch gelatinization. Carbohydrate Polymers 49: 479-490.

11. Shittu TA, Awonorin SO, Raji AO (2004) Evaluating some empirical models for predicting water absorption in African Breadfruit (Treculia Africana) seeds. Int J Food Propert 7: 585-602.

12. Laria J, Meza E, Mondragon M, Silva R, Pena JL (2005) Comparison of overal water uptake by corn kernel with and without calcium hydroxide at room temperature. J Food Eng 67: 451-456.

13. Tunde-Akintunde TY (2010) Water absorption characteristics of Nigerian Acha (Digitariaexilis). Int J Food Eng 6: 1-10.

14. Hsu KH (1983) A diffusion model with a concentration dependent diffusion coefficient for describing water movement in legumes during soaking. $\mathrm{J}$ Food Sci 48: 618-622.

15. Taiwo KA, Akanbi CT, Ajibola OO (1998) Regression relationships for the soaking and cooking properties of two cowpea varieties. J Food Eng 37: 331 334

16. Kubota K, Esaka M, Suzuki K (1984) Studies on simple convenient textual instrument and on physical properties of cooked soybean. J Fac Appl Biol Sci Hiroshima Univ 23: 9-24.

17. Yanagiuchi T, Yamamoto H, Miyazaki N, Nagano T, Wakai Y (1996) Influence of grain type on physical and chemical properties of rice for sake brewing. $J$ Ferment Technol 74: 97-103. 
Citation: Agarry SE, Afolabi TJ, Akintunde TTY (2014) Modelling the Water Absorption Characteristics of Different Maize (Zea Mays L.) Types during Soaking. J Food Process Technol 5: 326. doi:10.4172/2157-7110.1000326

18. Mizuma T, Tomita A, Kitaoka A, Kiyokawa Y, Wakai Y (2007) Water-absorption rate equation of rice for brewing sake. J Biosci Bioeng 103: 60-65.

19. Quast DG, da Silva SD (1977) Temperature dependence of hydration rate and effect of hydration on the cooking rate of dry legumes. J. Food Sci 42: 12991303.

20. Abu-Ghannam N, McKenna B (1997a) Hydration kinetics of red kidney beans (Phaseolus vulgaris L.). J Food Sci 62: 520-523.

21. Calzetta-Resio AN, Aguerre RJ, Suarez C (2003) Study of some factors affecting water absorption by amaranth grain during soaking. J Food Eng 60 : 391-396.

22. Addo, A, Bart-Plange A, Dzisi K (2006) Water absorption characteristics of Obatanpa and Mamaba Maize Hybrids(Zea mays). Int J Food Eng.

23. Verma RC, Prasad S (1999) Kinetics of absorption of water by maize grains. J Food Eng 39: 395-400.

24. Bhattacharya S (1995) Kinetics of hydration of raw and roasted corn semolina J Food Eng 25: 21-30.

25. Seyhan-Gurtas F, Ak MM,Evranuz EO (2001) Water diffusion coefficients of selected legumes grown in Turkey as affected by temperature and variety. Turkish J Agric 25: 297-304.

26. Mohsenin NN (1970) Physical Properties of Plant and Animal Materials, Gordon and Breach Science Publishers, New York.

27. Tagawa A, Muramatsu Y, Nagasuna T, Yano A, limoto M, et al. (2003)Water absorption characteristics of wheat and barley during soaking. Transactions of the ASAE 46: 361-366.

28. AOAC (1980) Official Methods of Analysis (13 th Edition). Washington DC Association of Official Analytical Chemists.

29. Peleg MA (1988) An empirical model for the description of moisture sorption curves. J Food Sci 53: 1216-1219.

30. Sopade PA, Obekpa JA (1990) Modelling water absorption in soybean, cowpea and peanuts at three temperatures using Peleg's equation. J Food Sci 55: 1084-1087.

31. Sopade PA, Ajisegiri ES, Badau MH (1992) The use of Peleg's equation to model water absorption in some cereal grains during soaking. J. Food Eng 15: 269-283.

32. Hung TV, Liu LH, Black RG, Trewhella MA (1993) Water absorption in chicken pea (C. arientum) and field pea (P. sativum) cultivars using Peleg's model. J Food Sci 58: 848-852.

33. Maharaj V, Sankat CK (2000) The rehydration characteristics and quality of dehydrated dasheen leaves. Can Agric Eng. 42: 81-85.

34. Sanni LO, Shittu TA, Ayoola O (2003) Water absorption kinetics in some Nigerian varieties of soybean (Glycine max) during soaking. Nigerian Food $J$ 21: 106-112.

35. Becker HA (1960) On the absorption of liquid water by the wheat kernel. Cereal Chem. 37: 309-323.

36. Eckhoff SR, Tso CC (1991) Starch recovery from steeped corn grits as affected by drying temperature and added commercial protease. Cereal Chem 68: 319320.
37. Lu R, Siebenmorgen TJ, Archer TR (1994) Absorption of water in long-grain rough rice during soaking. J Food Process Eng17: 141-154

38. Addo A, Bart-Plange A (2009) Kinetics of water sorption by egusi melon (cucumeropsisedulis) seeds. ARPN J. Agric. Biological Sci 4: 14-17.

39. Agu HO, Badau MH, Abubakar UM (2013) Modeling the water absorption characteristics of various local pearl millet grains and hungry rice (digitariaexilis) during soaking using peleg's equation. Focusing On Modern Food Industry 2 161-169.

40. Udoro EO, Kehinde AT, Olasunkanmi SG, Charles TA (2014) Studies on the physicochemical, functional and sensory properties of Gari processed from dried cassava chips. J Food Process Technol 5: 293.

41. Ali N (1974) Studies on some engineering aspects of parboiling of paddy. Unpublished Ph.D Thesis. Kharagpur: Indian Institute of Technology.

42. Tang J, Sokhansanj S, Sosulski FW (1994) Moisture-absorption characteristics of Laird lentils and hard shell seeds. Cereal Chem 71: 423-428.

43. Moss R (1977) The influence of endosperm structure, protein content and grain moisture on the rate of water penetration into wheat during conditioning. J Food Technol 12: $275-283$.

44. Busk GC (1984) Polymer-water interactions in gelation. Food Technol 58: 5964.

45. Ituen EU, Mittal JP, Adeoti JS (1986) Water absorption in cereal grains and its effect on their rupture stress. J Food Process Eng 8: 147-158.

46. Sopade, PA, Ajisegiri ES, Okonmah GN (1994) Modelling water absorption characteristics of some Nigerian varieties ofcowpea during soaking. Tropical Sci 34: 297-305

47. Turhan M, Sayar S,Gunasekaran S (2002) Application of Peleg's model to study water absorption in chickenpea during soaking. J Food Eng 53: 153-159.

48. Quicazán MC, Caicedo LA, Cuenca M (2012) Applying Peleg's equation to modelling the kinetics of solid hydration and migration during soybean soaking Ingeniería e Investigación 32: 53-57.

49. Lopez A, Pique MT, Clop M, Tasias J, Romero A, et al. (1995) The hygroscopic behaviour of the hazelnut. J Food Eng 25: 197-208.

50. Abu-Ghannam N, McKenna B (1997b) The application of Peleg's equation to model water absorption during the soaking of red kidney beans (Phaseolus vulgaris L.). J Food Eng 32: 391-401.

51. Sayar S, Turhan M, Gunasekaran S (2001) Analysis of chickpea soaking by simultaneous water transfer and water-starch reaction. J Food Eng 50: 91-98.

52. Haros M, Viollaz PE, Suarez C (1995) Effect of temperature and SO2 on the rates of water absorption of three maize hybrids. J Food Eng 25: 473-482.

53. Fan LT, Chu PS, Shellenberger JA (1963) Diffusion of water in kernels of corn and sorghum. Cereal Chem 40: 303-313.

54. Charan R, Prasad S (1996) Moisture diffusion during hydration of maize. J Food Sci Technol 33: 383-388.

55. Thakur AK, Gupta AK (2006) Water absorption characteristics of paddy, brown rice and husk during soaking. J Food Eng 75: 252-257. 